\title{
Laparoscopic-assisted treatment of pyometra associated with mammary fibroadenomatous hyperplasia in a cat
}

\author{
Tratamento de piometra associada à hiperplasia mamária fibroadenomatosa por videolaparoscopia \\ assistida em um gato
}

\begin{abstract}
Lucas Marques Colomé ${ }^{\text {Hiran Castagnino Kunert Filho }}{ }^{\mathrm{II}}$ João Pedro Scussel Feranti ${ }^{\mathrm{II}}$ Fabiane Reginatto dos Santos ${ }^{\mathrm{IV}}$ Luana Walendorff Sartori ${ }^{\mathrm{V}}$ Maurício Veloso Brun ${ }^{\mathrm{II}}{ }^{*}$
\end{abstract}

\section{- NOTE -}

\section{ABSTRACT}

This paper describes a case of laparoscopic-assisted ovariohysterectomy in a female cat presenting pyometra and mammary fibroadenomatous hyperplasia. Using four portals, mesovarium were ligated by titanium ligature clips whereas the uterine vessels were occluded by video-assisted conventional ligatures. There were no postoperative complications. Videoassisted technique can be an alternative method for treatment of pyometra and cystic endometrial hyperplasia in female cats.

Key words: laparoscopy, ovariohysterectomy, endosurgery, progesterone, uterus.

\section{RESUMO}

Este artigo descreve um caso de ovariohisterectomia por laparoscopia assistida em uma gata com sinais de piometra e hyperplasia mamária fibroadenomatosa. Usando quatro portais, os mesovários foram ligados com grampos de ligadura de titânio enquanto que os vasos uterinos foram ocluídos por ligaduras convencionais vídeo assistidas. Não houve complicações pósoperatórias. Esta técnica pode ser uma alternativa para tratamento de piometra e hiperplasia cística endometrial em gatas.

Palavras-chave: Laparoscopia, ovariohisterectomia, endocirurgia, progesterona, útero.

Female felines are often diagnosed and treated for diseases of the reproductive system due to hormonal changes, infection or trauma (TONIOLLO et al., 2000; KOLATA, 2002). Prolonged administrations of exogenous progestogens also seem to be associated with the development of pyometra (HEDLUND, 2005) and feline mammary hyperplasia (NELSON \& COUTO, 2001). Reports on pyometra in felines are scarce because female cats are induced ovulators and require mating for corpora lutea formation and secretion of progesterone, in contrast to the commonly observed clinical cases in dogs. As female dogs are not induced ovulators, the progesterone is secreted during the whole estral cycle contributing to the pathogenesis of this disease (NELSON \& COUTO, 2001; HEDLUND, 2005).

Nowadays, it is uncontested that surgery to remove the source of infection (ovariohysterectomy) when the animal is stable is the best current alternative for treatment of pyometra and mammary fibroadenomatous hyperplasia (TONIOLLO et al., 2000; HEDLUND, 2005).

Different video-assisted techniques for elective ovariohysterectomy in small animals have confirmed the success and the wide acceptance of this kind of procedure (MALM et al., 2004; MINGUEZ et al., 2005). However, reports on the use of videoassisted endoscopic surgery in the treatment of pyometra of female cats are still limited.

In this context, this study aimed to report the treatment of a female cat with pyometra and

\footnotetext{
'UniRitter Laureate International Universities, Porto Alegre, RS, Brasil.

IIFundação Educacional Barriga Verde (FEBAVE), Centro Universitário Barriga Verde (UNIBAVE), Orleans, SC, Brasil.

IIICentro de Ciência Rural (CCR), Universidade Federal de Santa Maria (UFSM), 97105-900, Santa Maria, RS, Brasil. E-mail: mauriciovelosobrun@hotmail.com.*Autor para correspondência.

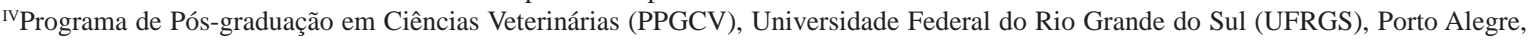
RS, Brasil.

vPrograma de Pós-graduação em Clínica e Cirurgia de Pequenos Animais, Instituto Qualittas, Porto Alegre, RS, Brasil. Received 05.07.12 Approved 09.03.13 Returned by the author 12.28.13 CR-2012-0150.R1
} 
mammary fibroadenomatous hyperplasia using video-assisted surgery in a large abdominal area.

A mixed-breed 5-year-old female cat weighing $4 \mathrm{~kg}$ exhibited purulent vaginal discharge and recurrent mammary hyperplasia affecting the left M3 and M4 right glands and M5 left gland (Figure 1A), which recurred after clinical treatment for about six months. According to clinical history, the animal received treatment to suppress the estrous cycle, however the drug administered was not defined. An abdominal ultrasound was taken, but a suitable visualization of the abdominal structures (uterus, ovaries and urinary bladder) was not possible due to the increased mammary volume. Blood tests, history and clinical examination demonstrated a stable condition to perform an ovariohysterectomy.

The animal received tiletamine and zolazepam (6mg kg-1, IM) as premedication. Anesthesia was induced with a combination of diazepam (0.5mg kg-1, IV) and propofol (2mg $\left.\mathrm{kg}^{-1}, \mathrm{IV}\right)$ and maintained under vaporized isoflurane at $100 \% \mathrm{O}_{2}$ using a partial rebreathing system. In addition, a combination of lidocaine $\left(15 \mathrm{mg} 3 \mathrm{~mL}^{-1}\right)$ and morphine $(0.4 \mathrm{mg}-0,16 \mathrm{~mL})$ was used for epidural anesthesia.

The animal was then kept in a Trendelenburg position and a $5 \mathrm{~mm}$ trocar was inserted in the ventral midline (umbilical region) for the laparoscope. The cavity was insufflated with medicinal $\mathrm{CO}_{2}$ using an open technique $\left(1 \mathrm{~L} \min ^{-1}\right.$ until $12 \mathrm{mmHg}$ ). Under direct visualization, two other trocars were introduced, a $5 \mathrm{~mm}$ one in the left lateral abdominal wall at the inguinal area and a $10 \mathrm{~mm}$ one in the contralateral position to avoid puncture of the mammary cyst (Figure 1B). A transparietal suture was applied through the wall using a curved $4 \mathrm{~cm}$-long needle in the body of the uterus; without puncturing the intraluminal content. After laceration of the suspensory ligament of the ovary, middle/large titanium hemostatic clips were applied. The number of clips kept in the patient for effective hemostasis was one on the left side and two on the right side. Uterine vessels and their branches were also occluded with the same clip size. The mesovarium, ovarian arteries and veins were sectioned with Metzenbaun scissors. An additional port was established in the right lateral abdominal wall in the prepubic region, lateral to the hyperplastic tissue to clamp the uterine body. The wound was enlarged in size $(1 \mathrm{~cm})$ to expose the uterus. During this maneuver, the uterus tore and its content leaked externally (but not into the abdomen). Gauze pads were promptly placed over the site of laceration to avoid direct contact between the purulent material and the peritoneum (Figure

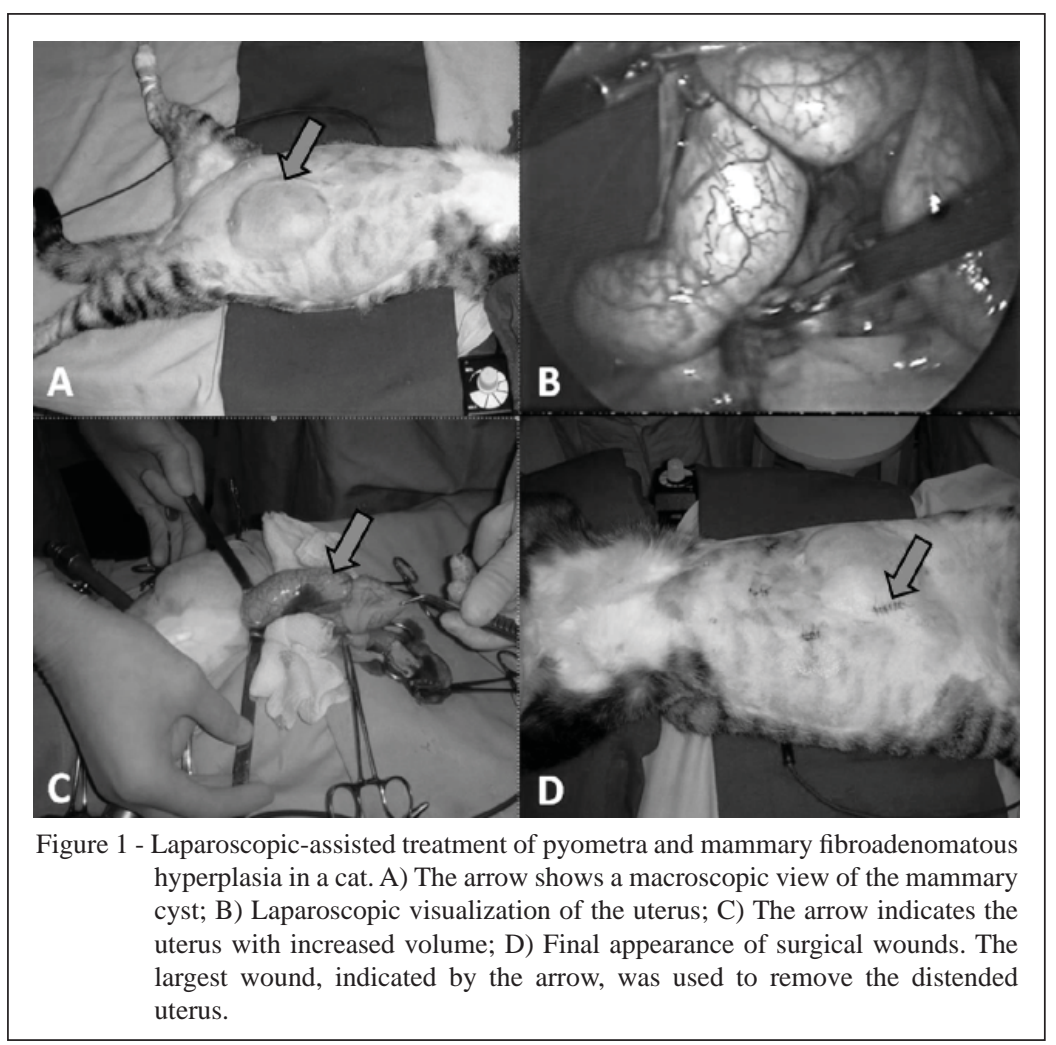

Ciência Rural, v.44, n.3, mar, 2014. 
1C). The uterine content was emptied entirely by luminal aspiration with a $20 \mathrm{~mL}$ syringe and an $18 \mathrm{G}$ hypodermic needle. During the open phase, a modified Halsted transfixation ligature with 30 polyglactin 910 and sectioning of uterine vessels and uterine body were carried out. Still under direct visualization, pneumoperitoneum was drained to check for possible bleeding when intra-abdominal pressure decreased. The four surgical access wounds were closed using 3-0 polyglactin with an interrupted cruciate suture pattern to close muscle and subcutaneous tissues and a 4-0 monofilament nylon in a simple interrupted pattern suture to close the skin (Figure 1D).

In addition to postoperative fluid therapy, ketoprofen (1mg $\mathrm{kg}^{-1}$, IM, SID, for 3 days) and tramadol hydrochloride ( $2 \mathrm{mg} \mathrm{kg}^{-1}$, IM, TID, for 2 days) were administered. Immediately after surgery and 7 days post-operatively, the fluid in the mammary cyst $(139 \mathrm{~mL})$ was drained by aspiration. The animal remained at the hospital for 4 days and clinical progression was satisfactory at this time.

Total operating time was 112 minutes, the time of surgery, relatively high when compared to what can be achieved by conventional access could be directly related to the complexity of the technique and to the learning curve for surgeons on the procedure applied for the disease treatment itself.

Initial $\mathrm{CO}_{2}$ volume to achieve the predefined pressure was $1.76 \mathrm{~L}$, and the total gas volume used was 28.3L. The owner reported no treatment complications when he was contacted by phone 12 months later.

According to MINAMI et al. (1997), laparoscopy is a valuable tool in the treatment of small animals. BRUN et al. (2006) had excellent results in the treatment of different pyometra presentations and reported that its use was safe and effective. According to our knowledge, this is the first case reported involving the treatment of pyometra and concurrent occurrence of mammary cysts in female cats using laparoscopy or video-assisted surgery. If conventional surgical technique had been chosen for this case, the presence of the mammary cyst would require a flank celiotomy to be performed, because a midline incision could be associated with the risk of cyst perforation and leakage of its content.

An open technique was chosen in order to create a pneumoperitoneum to reduce the risk of abdominal injuries. This decision has been further supported by the presumptive diagnosis of pyometra. We usually adopt this access rather than a Veress needle or a blind puncture with the first trocar for all small animal surgeries. The fourth port was established on the right abdominal wall, but unlike the case herein described, this procedure could have been set out at the beginning of the surgery to avoid the use of a transparietal suture to ligate the uterus, then reducing the risk of accidental puncture of the uterine lumen.

Another maneuver that could have been dismissed in this report was the occlusion of uterine vessels with clips, since the uterine hemostasis was carried out by conventional access. At first, it was thought about performing the full surgery by laparoscopic approach; however the presence of considerable amount of purulent content required the extracavitary exposure of the reproductive tract.

The successful result of the treatment described using this technique demonstrates its feasibility for the treatment of pyometra associated with mammary fibroadenomatous hyperplasia in female cats.

\section{REFERENCES}

BRUN, M.V. et al. Tratamento de diferentes apresentações de piometra em cães por cirurgia laparoscópica ou videoassistida. Medicina Veterinária, v.4, p.26-33, 2006.

HEDLUND, C.S. Cirurgia dos sistemas reprodutivo e genital. In: FOSSUM T.W. Cirurgia de pequenos animais. 2.ed. São Paulo: Roca, 2005. p.638-644.

KOLATA, R.J. Laparoscopic ovariohysterectomy and hysterectomy on African lions (Panthera leo) using the ultracision harmonic scalpel. Journal of Zoo and Wildlife Medicine, v.33, p.280-282, 2002. Available from: <http://www.ncbi.nlm.nih. gov/pubmed/12462496>. Accessed: nov. 11, 2013. doi: 10.3138/ jvme.38.4.408.

MALM, C. et al. Ovário-histerectomia: estudo experimental comparativo entre as abordagens laparoscópica e aberta na espécie canina. Intra-operatório-I. Arquivo Brasileiro de Medicina Veterinária e Zootecnia, v.56, n.4, p.457-466, 2004.

MINAMI, S. et al. Successful laparoscopy assisted ovariohysterectomy in two dogs with pyometra. Journal of Veterinary Medical Science, v.59, p.845-847, 1997.

MINGUEZ, R.E. et al. Ovariohisterectomia de gatas e cadelas pelo flanco. Revista Brasileira de Reprodução Animal, v.29, p.151158, 2005.

NELSON, R.W.; COUTO, C.G. Distúrbios da glândula mamária. In: _ Medicina Interna de pequenos animais. 2.ed. Rio de Janeiro: Guanabara Koogan, 2001. p.685-688.

TONNIOLO, G.H. et al. Piometra na espécie felina - Relato de um caso em Panthera onca. Brazilian Journal of Veterinary Research and Animal Science, [online], v.37, n.2, np., 2000. Available from: <http://www.scielo.br/scielo. php=S141395962000000200014 $>$. Accessed: mar. 3, 2012 doi:10.1590/S1413-95962000000200014. 